УДК 336.1:352

DOI https://doi.org/10.32849/2663-5313/2020.1.25

\title{
Ігор Бабін,
}

канд. юрид. наук, доиент,

дочент кафедри публічного права

Чернівецького національного університету імені Юрія Федьковича

\section{ПРАВОВА ПРИРОДА САМООПОДАТКУВАННЯ}

У статті розкриваються особливості правової природи самооподаткування. Серед вітчизняних та зарубіжних науковиів єдиної думки щодо розуміння сутності, місия та ролі самооподаткування в системі дохідних джерел територіальних громад немає. Здебільшого самооподаткування розглядається як інститут, що має податкову природу, обов'язковий платіж неподаткового характеру, благодійні внески, ініціативне бюджетування. Проблему породжує ще та обставина, що натепер в Украйні практично відсутнє законодавче регулювання иього фінансово-правового інституту.

Обгрунтовано, що, незважаючи на наявність у самооподаткування та податків низки спільних рис (публічний характер, індивідуальна безвідплатність, обов'язковий характер сплати), ототожнювати иі платежі не можна. Самооподаткуванню властивий иільовий характер, власна форма легалізаиії, власний суб'єкт та добровільний характер встановлення.

Встановлено, що самооподаткування неможливо віднести і до зборів. Умовою справляння коштів самооподаткування $є$ досягнення публічних иілей, а не надання спечіальної вигоди їх платникам. Сплата коштів у порядку самооподаткування у разі схвалення відповідного рішення зборами громадян чи на місиевому референдумі має обов'язковий характер. Несплата коштів самооподаткування має тягнути за собою заходи фінансово-правової відповідальності, тоді як наявність певних прав чи благ не залежить від сплати коштів самооподаткування. Несплата збору тягне за собою неможливість користуватися певними спеиіальними правами. Самооподаткуванню та зборам властиві $і$ деякі спільні ознаки: власне волевиявлення, здебільшого випадковий, разовий характер та порівняно незначний розмір.

Спільними ознаками самооподаткування та благодійних внесків можуть виступати иільовий та разовий характер. Відмінними ознаками є суб'єктний склад, юридичні підстави та порядок внесення відповідних внесків. Самооподаткування також необхідно відмежовувати від інічіативного бюджетування, яке останнім часом набуває популярності серед органів місиевого самоврядування як механізм консолідаиї фінансових ресурсів.

Ключові слова: самооподаткування, податок, збір, благодійні внески, ініціативне бюджетування, місцеве самоврядування, фінансове право.

Постановка проблеми. Ефективність діяльності органів місцевого самоврядування значною мірою залежить від достатності забезпечення їх фінансовими ресурсами. Втілення в життя конституційного принципу фінансової самостійності територіальних громад є одним із головних завдань сучасної української держави. Зрозуміло, що фінансова самостійність громад можлива за умови наявності достатніх власних доходів, оскільки міжбюджетні трансферти, а останнім часом і закріплені доходи (яскравим прикладом є нещодавня ситуація з акцизним податком, частина коштів від якого надходила до місцевих бюджетів) є показовим прикладом залежності територіальних громад від центральних органів державної влади. Традиційно у фінансовій та фінансово-правовій літературі власні доходи місцевого самоврядування розглядають через призму доходів від комунальної власності та місце- вих податків та зборів. Водночас досить цікавий і перспективний інструмент мобілізації фінансових ресурсів територіальними громадами, який має давню історію та вітчизняні і зарубіжні приклади ефективного використання, здебільшого залишається поза увагою. Йдеться про такий фінансово-правовий інститут, як самооподаткування населення

Аналіз останніх досліджень і публікацій. У науці фінансового права поки що не склався єдиний підхід до розуміння правової природи самооподаткування. Дане явище досить часто ототожнюють 3 іншими категоріями фінансового права, такими як податки, збори, благодійні внески і навіть ініціативне бюджетування. Відповідно, відсутні чіткі критерії розмежування даних явищ. В основу дослідження покладено теоретичні напрацювання як вітчизняних, так і зарубіжних вчених, зокрема О. Борисюка, К. Вєтрової, М. Гускі, М. Карасьова, О. Кірина, С. Коню- 
жевської, С. Лістрової, В. Левіної, О. Литвинової, В. Письменного, А. Сергєєва та інших.

Метою статті $€$ розкриття правової природи самооподаткування населення шляхом проведення порівняльного аналізу із суміжними фінансово-правовими явищами.

Виклад основного матеріалу. Натепер в Україні практично відсутнє законодавче регулювання інституту самооподаткування населення. Окрім Закону України «Про місцеве самоврядування в Україні», де в статті 1 міститься лише визначення самооподаткування, та Закону України «Про співробітництво територіальних громад», який в статті 16 передбачає можливість фінансування співробітництва за рахунок коштів самооподаткування, продовжуе також діяти Указ Президії Верховної Ради Української РСР 1984 року № 145 «Про самооподаткування сільського населення», зміст якого породжує більше питань, ніж дає відповідей на те, що таке самооподаткування і як його застосовувати. Практично відсутнє нормативне регулювання даного інституту і на рівні органів місцевого самоврядування. Навіть у статутних документах територіальних громад, що мають чи мали успішний досвід застосування самооподаткування, воно жодним чином не згадується і не розкривається механізм його реалізації. Відповідно, з'ясування правової природи самооподаткування населення має не тільки теоретичне, але й практичне значення.

Певні спроби законодавчого врегулювання були здійснені під час підготовки проектів Податкового кодексу, коли самооподаткування намагалися внести до переліку місцевих податків і зборів, та в жовтні 2018 року, коли Верховною Радою України було прийнято 3 законопроекти, що стосуються запровадження в Україні інституту самооподаткування, а саме: Проект Закону про внесення змін до деяких законодавчих актів України щодо самооподаткування населення № 9187 від 09.10.2018 р. та пов'язані з ним: Проект Закону про внесення змін до Податкового кодексу України щодо самооподаткування населення № 9190 від 10.10.2018 р. та Проект Закону про внесення змін до Бюджетного кодексу України щодо самооподаткування населення № 9091 від 10.10.2018 р. Однак, як і в попередніх законопроектах, самооподаткування населення продовжує розглядатись як різновид місцевих податків та зборів. На нашу думку, визнання самооподаткування податком призведе до знецінення самої ідеї самооподаткування як інструменту оперативного вирішення питань місцевого значення.
Від правильного визначення місця кожного виду платежу в системі доходів публічних суб'єктів, зокрема в системі обов'язкових платежів, залежить порядок його встановлення та введення, підстави справляння та стягнення [1, с. 146]. 3 цією метою необхідно провести чітку межу між окремими видами платежів, основою якої повинні стати не лише позиція законодавця, але і юридична природа та економічний зміст цих платежів.

Незважаючи на те, що самооподаткуванню та податкам властивий ряд спільних рис (публічний характер, індивідуальна безвідплатність, обов'язковий характер сплати), ототожнювати ці платежі не можна. По-перше, самооподаткуванню властивий власний спосіб встановлення - проведення загальних зборів або місцевого референдуму, тоді як щодо податків такі форми безпосередньої демократії прямо заборонені законодавством. Наприклад, у Законі «Про місцевий референдум» Республіки Польща прямо вказано, що проведення референдуму громади є єдиною допустимою формою встановлення самооподаткування мешканців [2]. На думку Є. Конюжевської, використання референдуму щодо самооподаткування мешканців також може бути підтримане необхідністю залучення членів громади до виконання громадських завдань $\mathrm{i}$, як результат, формування їхньої відповідальності за функціонування своєї громади [3, с. 606].

По-друге, самооподаткування відрізняється від податків суб'єктом встановлення. Суб'єктом встановлення місцевих податків $€$ представницький орган місцевого самоврядування (відповідна місцева рада), а самооподаткування - безпосередньо мешканці відповідної територіальної громади. Це пояснюється тим, що межі компетенції представницьких органів місцевого самоврядування у сфері оподаткування обмежені такими діями, як вибір із встановленого на рівні закону переліку місцевих податків і зборів конкретного податку чи збору, розробка та конкретизація змісту чітко визначених елементів юридичної конструкції вибраного місцевого податку чи збору, а також здійснення процесу щодо прийняття відповідного рішення про введення даного місцевого податку чи збору в дію на теритоpiї своєї юрисдикції [4, с. 24-25]. Водночас стаття 1 Закону України «Про місцеве самоврядування в Україні», виступаючи проявом конституційного принципу самостійності місцевого самоврядування, передбачає можливість за рішенням зборів громадян залучити на добровільній основі кошти населення відповідної території у формі самооподаткування для фінансування разових цільових 
заходів соціально-побутового характеру. Разом із тим історія самооподаткування в Україні показує непоодинокі випадки, коли місцеві ради без проведення загальних зборів мешканців чи місцевого референдуму намагалися встановити на своїй території самооподаткування. Наприклад, Малоорчицькою сільською радою на Харківщині було встановлено самооподаткування сільського населення на 2013 рік. Однак прокуратурою Зачепилівського району, що є яскравим підтвердженням нашої позиції щодо суб'єкта встановлення самооподаткування, було внесено подання сесії сільської ради про скасування незаконного рішення з метою захисту прав громадян. Своє подання прокуратура обгрунтовувала тим, що, згідно з вимогами нового Податкового кодексу України, самооподаткування не входить до переліку податків та зборів, які мають право встановлювати місцеві ради [5].

По-третє, самооподаткуванню на відміну від податків властивий добровільний характер встановлення. Мешканці територіальної громади на загальних зборах чи місцевому референдумі добровільно погоджуються на введення самооподаткування, його розмір, порядок сплати, цілі використання зібраних коштів чи, навпаки, не погоджуються, тоді як 3 платниками податків зазначені питання не обговорюються, їхні думки та позиції можуть не братися до уваги. Встановлення податків відбувається в односторонньому з боку суб'єкта публічної влади обов'язковому порядку [6, с. 47-48]. Не можемо погодитися з В. Письменним у тому, що механізм справляння платежів із самооподаткування передбачає добровільне внесення громадянами грошових коштів для фінансування заходів із благоустрою населених пунктів, розвитку комунального господарства та побутової сфери, ї̈ об'єктів й інфраструктури [7, с. 35]. Оскільки після затвердження рішення про встановлення самооподаткування на загальних зборах мешканців чи місцевому референдумі сплата коштів самооподаткування, як і сплата податків, набуває обов'язкового характеру. У практиці зарубіжних країн трапляються випадки, коли в муніципальних правових актах самооподаткування намагаються чітко та однозначно назвати податком та поширити на нього положення податкового законодавства, в тому числі в частині юридичної відповідальності за невиконання податкового зобов'язання, однак самі науковці, що наводять такі приклади, зазначають безперспективність такого підходу на підставі того, що самооподаткування має більше відмінних, ніж спільних ознак з податками [8, c. 56-59].
По-четверте, від податків самооподаткування відрізняється цільовим характером. Причому цільовий характер має як саме введення самооподаткування, так і видатки зібраних коштів, що є винятком із принципу загального покриття видатків бюджету, характерного для податків. Як зазначає М. Гускі, самооподаткування є інструментом накопичення доходів громади на чітко окреслену ціль [9, с. 140]. Абстрактне формулювання цілі самооподаткування може бути підставою для визнання його незаконним. Наявний досвід показує, що самооподаткування встановлювалось для фінансування вуличного освітлення, реконструкції пам'яток культури, догляду за культовими спорудами, кладовищами, вивезення сміття, очищення криниць.

Відповідно до пункту 6.2. статті 6 Податкового кодексу України збором (платою, внеском) є обов'язковий платіж до відповідного бюджету, що справляється 3 платників зборів, 3 умовою отримання ними спеціальної вигоди, у тому числі внаслідок вчинення на користь таких осіб державними органами, органами місцевого самоврядування, іншими уповноваженими органами та особами юридично значимих дій. Як бачимо $з$ даного визначення, кошти самооподаткування неможливо віднести і до зборів. Адже умовою справляння коштів як зборів $€$ надання спеціальної вигоди, в тому числі здійснення юридично значимих індивідуалізованих стосовно конкретного платника зборів дій, а не публічні цілі. Вирішення питань місцевого значення не може розглядатися як виконання будь-яких юридично значимих дій стосовно особи, оскільки зібрані кошти спрямовуються на задоволення інтересів усіх чи певної частини мешканців, що проживають на території цієї територіальної громади. Відрізняються збори і самооподаткування наслідками несплати. Несплата збору тягне за собою неможливість користуватися певними спеціальними правами (наприклад, несплата рентної плати за спеціальне використання води тягне за собою неможливість спеціального водокористування, і т. д.) Несплата коштів самооподаткування має тягнути за собою заходи фінансово-правової відповідальності (через законодавчу неврегульованість фінансово-правового інституту самооподаткування неврегульованим залишається і питання відповідальності), тоді як наявність певних прав чи благ не залежить від сплати коштів самооподаткування (особа зможе користуватись вуличним освітленням, заасфальтованою дорогою, урнами для сміття та іншими благами, на які збирались кошти за допомогою самооподаткування, 
незалежно від власної участі в ньому). Разом із тим самооподаткуванню та зборам властиві і деякі спільні ознаки. Суб'єктами самооподаткування, як і платниками зборів, особи стають здебільшого у зв'язку з власним волевиявленням. У першому випадку - підтримуючи рішення про введення самооподаткування на загальних зборах чи місцевому референдумі, в другому випадку - звертаючись до відповідних владних органів за вчиненням певних дій. Крім того, самооподаткуванню, як і зборам, властивий здебільшого випадковий, разовий характер та порівняно незначний розмір.

Кошти самооподаткування населення належать до групи неподаткових доходів бюджетів, тому їх необхідно відрізняти від іншого виду власних доходів місцевих бюджетів - благодійних внесків. Цивільний кодекс України розглядає благодійну допомогу як пожертву. Це узгоджується зі статтею 6 Закону України «Про благодійну діяльність і благодійні організації», у якій йдеться про благодійні пожертви. Під час укладення договорів про пожертву застосовуються положення про договір дарування, якщо інше не встановлено законом (стаття 729 ЦКУ). Такі договори можуть укладатися як в усній, так і в письмовій формі. Тобто письмова форма договору не обов'язкова. Однак договір оформляють, якщо благодійник наполягає на оформленні такого договору й хоче вказати напрями витрачання благодійних внесків.

Благодійний внесок - це добровільний внесок фізичної (юридичної) особи, наданий бюджетній установі, яка належить до сфер благодійної діяльності. Бюджетне законодавство розглядає такі внески як власні надходження бюджетних установ, які є складовою частиною спеціального фонду державного та місцевих бюджетів. Згідно 3 частиною 4 статті 13 Бюджетного кодексу України благодійні внески у грошовій формі можна використати на організацію основної діяльності бюджетних установ, якщо благодійник не визначив напрями витрачання благодійних внесків. У такому разі керівник бюджетної установи (набувач) спрямовує їх на першочергові потреби, пов'язані тільки 3 основною діяльністю установи [10].

Таким чином, об'єднуючими ознаками самооподаткування та благодійних внесків можуть виступати цільовий та разовий характер. Послідовним законодавчим рішенням було би внесення відповідних змін до Податкового Кодексу України за прикладом благодійних внесків, стосовно яких Кодекс передбачає податкову знижку. Відмінними ознаками є суб'єктний склад, юридичні підстави та порядок внесення відповідних внесків. Кошти самооподаткування сплачуються фізичними особами (мешканцями) на підставі рішення, прийнятого на загальних зборах мешканців чи місцевому референдумі, в обов'язковому порядку, визначеному фінансовим законодавством. Своєю чергою, благодійні внески вносяться до місцевих бюджетів фізичними та юридичними особами на добровільній основі без обов'язковості проведення загальних зборів чи місцевого референдуму. Пожертвами може виступати різноманітне майно, в тому числі грошові кошти, речі, майнові права. Порядок внесення пожертв визначається цивільним законодавством.

Самооподаткування також необхідно відмежовувати від ініціативного бюджетування, яке останнім часом набуває популярності серед органів місцевого самоврядування як механізм консолідації фінансових ресурсів. Ініціативне бюджетування - це сукупність різноманітних практик, що засновані на громадській ініціативі з вирішення питань місцевого значення за безпосередньої участі громадян у визначенні та виборі об'єктів витрачання бюджетних коштів [11]. Ініціативне бюджетування останніми роками отримало велике поширення в Україні і зарекомендувало себе як досить ефективна бюджетна практика.

Ініціативне бюджетування дозволяє швидко прийняти рішення про збір коштів i оперативно їх залучити. При цьому збір коштів відбувається з урахуванням індивідуальних можливостей благодійників. Водночас є небезпека використання схем «пожертвування в обмін на лояльність органів влади» стосовно підприємців, а також тиску на громадян з метою збору необхідного мінімуму пожертв. Крім того, необхідно брати до уваги недовіру мешканців у зв'язку з відображенням коштів не як співфінансування конкретного проекту, а як «благодійних внесків» у бюджет. Водночас самооподаткування дозволяє залучити все населення у вирішення питань місцевого значення, хоча таке залучення іноді може бути формальним. Ще одна перевага полягає у більшому ступені ймовірності збору прогнозованого обсягу коштів. Своєю чергою, недоліком самооподаткування є значні видатки на залучення коштів, оскільки організація місцевого референдуму за вартістю майже сумірна з величиною зібраних коштів.

\section{Висновки}

Підсумовуючи вищевикладене, самооподаткування необхідно розглядати як самостійний вид обов'язкового платежу, що немає 
податкового характеру та використовується для вирішення питань місцевого значення, розмір та порядок введення і використання якого встановлюється самостійно населенням на загальних зборах чи місцевому референдумі. У подальшому законодавчому врегулюванні необхідно враховувати зазначені особливості і підходити до самооподаткування не як до різновиду місцевих податків і зборів, а як до одного з інструментів прямої демократії на місцевому рівні, народної фінансової ініціативи. Введення самооподаткування населення має вагоме значення для розвитку територіальних громад. Самооподаткування дозволяє громадам отримати додаткові фінансові ресурси для реалізації цілей місцевого значення, підвищує громадянську активність мешканців, сприяє їх залученню до спільного вирішення проблем територіальної громади, підвищує рівень відповідальності органів місцевого самоврядування

\section{Список використаних джерел:}

1. Бабін I.I. Податкове право : навчальний посібник. Київ : Видавничий дім «КОНДОР», 2018. 488 c.

2. Ustawa o referendum lokalnym $\mathrm{z}$ dnia 15 wrzesnia 2000 r. Dz. U. $2000 \mathrm{Nr} 88$ poz. 985 s.

3. Koniuszewska Ewa. Referendum for selftaxation as a form of participation of commune residents in the shaping of its revenues. Optimization of Organization and Legal Solutions concerning Public Revenues and Expenditures in Public Interest (Conference Proceedings), ed. Ewa Lotko, Urszula K. Zawadzka-Pąk, Michal Radvan. Bialystok-Vilnius, 2018. S. 603-614. DOI 10.15290/oolscprepi.2018.44

4. Бабин И.И. Современная система местных налогов и сборов Украины. Societas et Iurusprudentia. 2016. Volume IV., Issue 3. P. 21-40.

5. Прокуратура захистила селян від незаконного податку. Прес-служба прокуратури Харківської області. URL: https://khar.gp.gov.ua/ua/news.html? $\mathrm{m}=$ publications\&_t=rec\&id=117222\&fp=3220 (дата звернення: $11.11 . \overline{2} 019)$.

6. Бабін I.I. Юридична конструкція податку : монографія. Чернівці: Рута, 2008. 272 с

7. Письменний В. Самооподаткування: історичний досвід та сучасні проблеми. Світ фінансів. 2008. № 3(16). С. 30-36.

8. Кирин А.А. О средствах самообложения граждан: правовой анализ. Молодой ученый. 2017. № 35 (169). C. 56-59

9. Hyski Marcin. Problemy samoopodatkowania się mieszkańców gminy. Infrastruktura $i$ ekologia terenów wiejskich. 2009. Nr. 4. S. 135-147.

10. Лістрова С. Облік благодійних внесків у грошовій формі в бюджетних установах URL : https: //bz.ligazakon.ua/ua/magazine article/BZ010142 (дата звернення: 11.11.2019).

11. Левина В. Сходства и различия самообложения граждан и инициативного бюджетирования. Экономика и жизнь. 2016. № 20. URL : https: https://www.eg-online.ru/article/315252/ (дата звернення: 11.11.2019)

The article reveals features of the legal nature of self-taxation. There is no consensus among national and foreign scholars on the understanding of the nature, place and role of self-taxation in the system of profitable sources of territorial communities. For the most part, self-taxation is considered to be an institute with a tax nature, mandatory non-tax payment, charitable contributions, initiative budgeting. The problem is also caused by the fact that today in Ukraine there is practically no legislative regulation of this financially legal institute.

It is justified that, despite the existence of self-taxation and taxes, a number of common features (public nature, individual non-gratuity, mandatory payment), it is impossible to equate these payments. Self-taxation is intrinsic to the target character, its own form of legalization, its own entity and its voluntary nature.

It is established that self-taxation cannot be attributed to fees. Self-taxation is a condition for achieving public goals, not for giving special pay to their payers. Payment for self-taxation is obligatory in the event of approval of the relevant decision by a public meeting or in a local referendum. Non-payment of selftaxation should entail financial liability measures, while the existence of certain rights or benefits does not depend on the payment of self-taxation. Non-payment of the fee entails the inability to exercise certain special rights. There are also some common features of self-taxation and fees: self-will, mostly casual, oneoff, and relatively small character.

Self-taxation and charitable contributions can be targeted and one-off. Distinctive features are the subject composition, the legal grounds and the procedure for making appropriate contributions. Self-taxation also needs to be distinguished from initiative budgeting, which has recently become more popular with local governments as a mechanism for consolidating financial resources.

Key words: self-taxation, tax, fee, charitable contributions, initiative budgeting, local government, financial law. 